The President of the Board says nothing of buildings long condemned as unsatisfactory and remaining unrepaired. Children lounging about the streets are a nuisance to themselves and everybody else, and rapidly deteriorate. This misguided leisure is being rectified by the allocating of camps and hiring of extra halls. Authorities have been told that children may be admitted to school before protection is completed. The 400,000 at present "receiving no schooling or care at all" present an urgent problem. In some cases "provision has been made and the children are not attending", and it is stated there are those who "bolster up evacuation by keeping schools closed". The announcement of compulsory school attendance for older children is a step in the right direction. Examinations should go on and full-time schooling be made compulsory as soon as possible. Lord De La Warr realizes that "education is not less important in wartime but more so". At a national conference of secretaries of the National Union of Teachers, a resolution was passed warmly welcoming "the decision of His Majesty's Government to enforce compulsory school attendance in evacuable areas no less than in neutral and reception areas".

\section{Evacuation and Science Work in Schools}

The transference of schools from 'vulnerable' to 'safe' areas in Britain, where they now work in conjunction with other schools of the same type, was a necessary part of the scheme adopted at the outset of the War to minimize loss of life in the event of air attacks upon the civil population. Since last September, normal educational work has therefore not been possitle for a very large number of secondary school pupils, and whatever gain there may have been for those from towns coming into closer contact with Nature, it is perhaps offset by reduced teaching and laboratory facilities. Even the better equipped of secondary schools cannot be expected to accommodate double the usual number of science classes, and though in many instances the amount of time devoted to science subjects has not been seriously curtailed, the work is often done in unfavourable circumstances, especially as regards the senior work. It is difficult to accommodate all the senior students in the small advanced laboratories found in most secondary schools even when a system of 'double shifts' is arranged, so that practical work has suffered more than theoretical teaching. The standard of proficiency of pupils who will leave school this year to continue at the universities will be examined with much interest. That the experiment of evacuating schools was a wise one, despite the dislocation involved, there can be no doubt, and the authorities are doubtless watching its consequences so far as secondary and higher education is concerned.

\section{Health of the School Child}

Sir Arthur MacNaLty's report for 1938 on "The Health of the School Child" has been issued by the Board of Education (H.M. Stationery Office. 1s. 3d.). The introduction considers the circumstances rendering necessary the evacuation of school children from large urban centres of population and its effect upon the school medical service. During the year the nutrition of $1,674,023$ children was assessed at routine medical inspections, and $\mathbf{1 4 \cdot 5}$ per cent were found to be excellent, $74 \cdot 2$ per cent normal, $10 \cdot 8$ per cent subnormal and 0.5 per cent bad. During twenty years, improvement in the nutrition of the school child is striking. Thus in Sheffield, compared with 1920, five-year-old boys average nearly 2 inches taller and $3 \mathrm{lb}$. heavier, and five-year-old girls $1 \cdot 4$ inches taller and $1 \mathrm{lb}$. heavier; twelve-year-old boys are more than 2 inches taller and $9 \frac{3}{4} \mathrm{lb}$. heavier, and twelveyear-old girls 3 inches taller and no less than $12 \cdot 4 \mathrm{lb}$. heavier. The numbers of children in receipt of free meals or milk continue to increase-from 535,300 in 1936-37 to 687,855 now-and the milk-in-schools scheme is in operation in 87 per cent of public elementary schools. Much information is given respecting medical inspection and treatment, hearing of children, the school dental service, and the care of the young child.

\section{Rhodes-Livingstone Institute, Northern Rhodesia}

A BRIEF note on the work of the Rhodes-Livingstone Institute since its inception in 1937 prefaces a contribution on "Anthropology as a Public Service" by Mr. Godfrey Wilson in the current issue of Africa (13, 1 ; January 1940). This Institute, it may be remembered, was founded largely through the efforts and interest of Sir Hubert Young, then governor of Northern Rhodesia, and was the first institute for systematic sociological research to be established in colonial Africa. In the words of the founders, it was intended "as a contribution to the scientific efforts now being made in various quarters to examine the effect upon native African society of the impact of European civilization." In the first instance, funds were asked for three years only, with a view to a special appeal in 1940, a year specially linked with the two men whom the Institute commemorates. It is the centenary year of Livingstone's departure for Africa and the jubilee year of the foundation of the two Rhodesias by Cecil Rhodes.

The Institute is not a Government department but an independent body governed by trustees. Although for the moment the bulk of the income is derived from Northern Rhodesia, contributions are made by all the Governments from Southern Rhodesia to Uganda. Not only has the museum founded in memory of Livingstone in 1934 been incorporated in the Institute, its curator acting as the secretary, but also two research officers have been appointed, of whom Mr. Wilson is one, and the results of their investigations will be published in a series, the Rhodes-Livingstone Papers, to which non-members are also invited to contribute.

\section{Pioneers in Amerindian Portraiture}

The February issue of Man is a Catlin centenary number, and Mr. L. J. P. Gaskin recalls that on February 1, 1840, George Catlin, artist, traveller and ethnographer, opened his North American Indian Museum and Gallery in the Egyptian Hall, Piceadilly, 
London (see also Nature, January 27, p. 158). Catlin was a self-taught artist and ethnographer. By contrast, Paul Kane (1810-71) was an artist by training and profession, and in his home in Toronto he had been familiar with the appearance and dress of Indians of various tribes who visited that seat of government. After travelling in the United States and studying in Europe, he set out on the first of his two expeditions among the Indians in 1845, when he spent five and a half months in recording portraits of "the principal chiefs, and their original costumes to illustrate their manners and customs, and to represent the scenery of an almost unknown country". In 1846 Kane started on his second and more important journey, which occupied two years and six months and extended across the continent to Fort Victoria. He did not keep a journal during his travels, and his book "Wanderings of an Artist among the Indians of North America" (1859) appears to have been written from memory.

Kane's sketches, exhibited on his return, attracted much interest, and a number of pictures were commissioned from him, some by the Government. Some of his pictures are now in the National Gallery, Ottawa, the House of Commons, Ottawa, and the Royal Ontario Museum of Archæology, Toronto. Of his field sketches, some are likewise preserved in Toronto, while a number are in the possession of David I. Bùshnell, jun. Reproductions of these have now been published with an account of the artist's life and work by the present owner (Smithsonian Miscell. Collect., 99, I ; 1940). They show a number of variations, important in an ethnographical sense, from the studio portraits and studies painted later.

\section{Tibetan Ceremonial and the Dalai Lama}

Since the revelation of the reincarnation of the late Dalai Lama in the body of a small boy and his entry into Lhasa, further observances of the ritual ceremonial have affirmed the youthful succession in his position-in this instance all the more necessary in view of the slight discrepancy between his age and the period of time that has elapsed since the death of his predecessor. Among these is the assumption of the new name or names by which the Dalai Lama will be known officially in future. These are, it is stated (The Times, February 9), Jampel Ngawang Lobsang Yishey Tenzing Gyatso, of which the meaning is "Tender Glory, Mighty in Speech, Excellent Intellect, Absolute Wisdom, Holding to the Doctrines, and Ocean-Wide". These names derive from titles of former Dalai Lamas, including the first, which was bestowed by the Mongol prince Yushi Khan.

Large numbers of Buddhist priests and nuns are now present in Lhasa for the installation ceremonies, and have attended the ceremonial performances which have taken place in the courtyard of the Potala, the vast monastic establishment in which the Dalai Lama resides. The important part of the New Year observance, as with many primitive peoples, and also among the more primitive of the
European peasantry even to-day, is the ceremonial of driving out all the evil influences of the Old Year. In Tibet this is of especial significance in view of the element of 'devil-worship' which has been introduced into the practices of Tibetan Buddhism, and the ecstatic 'devil-dances' in which its followers indulge more especially in eastern Tibet.

On this occasion, it is reported in a dispatch from Lhasa (The Times, February 12), the dancers, wearing masks representing the heads of stags or bulls and grinning skulls with fangs, enacted the reception for the skeleton dance which was performed by four skeleton dancers, with two attendant death's heads, scattering ashes. A magician wearing an apron of bones and a tall black hat topped with a fan-shaped ornament conjured spells from a skull while spinning in a rhythmic dance, which was the preliminary to ceremonies performed over an artificial corpse, which no doubt represented the Old Year, although this is not stated. Fire, as always a purificatory agent, appeared in the ceremonial when pictures of Tibetan devils were burned.

\section{Forgotten Methods of Painting}

IN his discourse on "Forgotten Methods of Painting" at the Royal Institution on February 2, Mr. Hesketh Hubbard spoke of the almost forgotten sfumato and botizar systems of oil painting, and dealt with the method of dusting dry powdered pigment over a sticky mordant which was used by some of the sixteenth and seventeenth century painters for laying certain pigments-a method known as 'strowing'. $\mathrm{He}$ outlined the technique of the fourteenth century English painters who worked in water-colour on woven linen; the linen was first saturated with gum. water, and then stretched over coarse woollen and frieze cloths which absorbed most of the colour, leaving the linen transparent after painting. The method of elydoric painting, or painting miniatures in oil whilst the painting ground was submerged in water, and the techniques of encaustic painting were among the topics mentioned.

In his ceaseless search for new pigments, before the chemist rendered him much assistance, the painter had not despised even the food upon his table. The great Paul Sandby himself had converted into pigment burnt crusts and peas that had been cooked to a cinder. Mr. Hubbard said that there is no reason to suppose that the painter has discovered all the manifold uses of his materials; the more media he has at his disposal the less restricted will be the mental outlook of the painter. Every medium of painting shares a frontier with one or more other media. At one point tempera touches fresco; at another it borders on oil painting. Glass painting and enamelling share much in common. It is along these frontiers, in the region of mixed methods, that the painter, in these latter days of painting will, in Mr. Hubbard's opinion, find the most profitable fields for experiment and research. For the same reason, the painter and student might profitably turn their attention, at least in their leisure hours, to some of the forgotten methods of painting. 